\title{
Genetic Variability and Interrelationship among the Agro-economic Traits in Psyllium Accessions
}

\section{Dilshad Ahmed ${ }^{1 *}$ and RK Lal ${ }^{2}$}

${ }^{1}$ Department of Botany, University of Lucknow, Uttar Pradesh, India

${ }^{2}$ Department of Genetics and Plant Breeding, CSIR-Central Institute of Medicinal

and Aromatic Plants, P.O. CIMAP, Uttar Pradesh, India

*Corresponding Author: Dilshad Ahmed, Department of Botany, University of Lucknow, Uttar Pradesh, India.
Received: June 15, 2021

Published: June 29, 2021

(C) All rights are reserved by Dilshad Ahmed and RK Lal.

\section{Abstract}

The present study aims to understand the degree, amount and nature of relationship between different morphometric and yield associated traits and path coefficient analysis in medicinally important plant. The genotypic correlation coefficient ( $\left.r_{g}\right)$ was higher than phenotypic correlation coefficient $\left(r_{p}\right)$, suggesting inherent relations for selected traits at their genotypic level. Highest direct contributor to seed yield was husk yield/plot (0.88), whereas, the lower indirect contributor to seed yield was plant height. The highest heritability and highest genetic advance were observed for the traits panicle/plant 98.57\%, 157.79\%, respectively suggesting it was possibly governed due to cumulative gene action. On the basis of overall mean performance, character contribution, correlation, path coefficient analysis, heritability and genetic advance, accessions GSD 36, GSD 38, GSD 42, GSD 45, and GSD 47 were identified as highest seed yielding accessions and could be exploited for commercial cultivation.

Keywords: Correlation; Genotypic Coefficient of Variation; Phenotypic Coefficient of Variation; Heritability; Medicinal Plant

\section{Introduction}

Plantago ovata (Forsk), Psyllium (Plantaginaceae), is one of the major medicinal crops having international acceptance and industrial significance [1]. The genus comprises 200 species, ten of which occur in India [2]. Plantago ovata is one of them, valued for its seeds and husks which have been used in indigenous medicine for many centuries all over the world [3]. Other species of Plantago selected for study were Plantago lanceolata, P. arinaria and $P$. psyllium, produces very less quantity of seed husk, therefore, none of these preferred in pharmaceutical industries [4]. It is used predominantly in stomach disorders such as diarrhoea, ulcers, gonorrhoea, piles, cough, chronic dysentries of amoebic and bacillary origin and also used for treating constipation and intestinal disorders since ayurvedic medicines [5]. The husk from the seed has property of absorbing and retaining water therefore it works as an antidiarrhoeal drug. Psylliun is an good source of dietary fiber and has hypocholesterolemic activity and widely accepted as food additives in several processed material like cookies, ice-cream, bread etc. [6]. The origin of plant is west Asia and it was introduced into India during the muslim settlement in the middle ages [3]. India dominates the world market in the production and export of psyllium and it is also the main foreign exchange earner crop of India [1]. India is the only exporter of psyllium to the world market and about 80 to 90 percent produce is exported but is not able to meet global demand on account of low production and productivity. The nearly stagnant yield of isabgol is due to narrow genetic base and use of traditional breeding techniques with little or no understanding of genetic architecture of the plants [3]. Only few improved varieties like Niharika and Mayuri for North Indian plains, H15 for Haryana and GI 1 and GI 2 for Gujarat, Rajasthan 
and Madhya Pradesh available for cultivation [3]. Therefore in the scenario of increasing demand and lack of improved varieties there is instant need to develop high-yielding varieties of this crop and to look at suitable locations for growing this crop in other states of the country for further export promotion. This present study was carried out to identify the high seed and husk yielding genotypes and to evaluate the accessions of Plantago germplasm with special regard to: (a) genetic variability, associations among the economic traits in respect to seed yield, the nature and magnitude of various elite genetic parameters and (b) generate information on the basis of direct and indirect effects on seed yield through path analysis to develop an efficient selection criterion for genetic improvement.

\section{Materials and Methods}

Plant materials

The current experiments were carried out among 50 indigenous and exotic accession/genetic stocks of Plantago (Table 1) representing four species: P. ovata Forsk., P. lanceolata L., $P$. arinaria Waldst., P. psyllium. L.

\section{Field preparation and allied practices}

The genetic stocks were evaluated by growing in the research farm of CSIR- Central Institute of Medicinal and Aromatic Plants, Lucknow, Uttar Pradesh, India located at $26.5^{\circ} \mathrm{N}$ latitude and $80.50^{\circ} \mathrm{E}$ longitude, $120 \mathrm{~m}$ above mean sea level. The climate was semi-arid to sub-tropical in nature. The minimum and maximum night and day temperatures ranged $9-12^{\circ} \mathrm{C}$ to $16-19^{\circ} \mathrm{C}$ respectively during growth period and from $26-31^{\circ} \mathrm{C}$ to $36-40^{\circ} \mathrm{C}$ during harvesting time respectively. The average rainfall during the growing season 4 - $6 \mathrm{~mm}$ according to weather data of the Metrological Laboratory of CSIR-CIMAP, Lucknow in two successive years 20152016 and 2016 - 2017 in randomized complete block design (RBD) with three replications and $0.90 \mathrm{~m}^{2}$ plot size. The crop received normal intercultural operations such as weeding, irrigations and fertilizer applications (60 kg N, $30 \mathrm{~kg} \mathrm{P}_{2} \mathrm{O}_{5}$ and $30 \mathrm{~kg} \mathrm{~K}_{2} \mathrm{O}$ per hectare).

\section{Statistical analysis}

The morpho-metric traits were recorded for statistical analysis from five randomly selected plants from each accession in three replicates with respect to nine important characters as following: plant height $(\mathrm{cm})=\mathrm{X} 1$, branches $/$ plant $=\mathrm{X} 2$, panicles $/$ plant $=\mathrm{X} 3$, panicle length $(\mathrm{cm})=X 4$, peduncle length $(\mathrm{cm})=X 5$, inflorescence length $(\mathrm{cm})=\mathrm{X} 6$, seed yield $(\mathrm{g} / \mathrm{plot})=\mathrm{X} 7$, husk yield $(\mathrm{g} / \mathrm{plot})=\mathrm{X} 8$, and Swelling factor $(\mathrm{ml} / \mathrm{g})=\mathrm{X} 9$. The mean data were collected and subjected to statistical analysis for variances, co-variance, variability, heritability and genetic advance using statistical software ver. 0.3 based on Singh and Chaudhary [7] and Panse and Sukhatme [8] at the Department of Genetics and Plant Breeding CSIR-CIMAP, Lucknow.

\begin{tabular}{|c|c|c|}
\hline $\begin{array}{l}\text { Sr. } \\
\text { No. }\end{array}$ & $\begin{array}{l}\text { Accession } \\
\text { code }\end{array}$ & Origin/Places of collections \\
\hline 1. & GSD 1 & Bulgaria \\
\hline 2. & GSD 2 & USA \\
\hline 3. & GSD 3 & USA \\
\hline 4. & GSD 4 & Pakistan \\
\hline 5. & GSD 5 & Maharashtra, India \\
\hline 6. & GSD 6 & Baluchistan, Pakistan \\
\hline 7. & GSD 7 & Uttaranchal (Pantnagar), India \\
\hline 8. & GSD 8 & Himanchal Pradesh, India \\
\hline 9. & GSD 9 & Gujarat, India \\
\hline 10. & PL* 10 & Malaysia \\
\hline 11. & GSD 11 & Gujarat (Sidhpur), India \\
\hline 12. & GSD 12 & Uttar Pradesh (Lucknow), India \\
\hline 13. & GSD 13 & Uttar Pradesh (Lucknow), India \\
\hline 14. & GSD 14 & Uttar Pradesh (Lucknow), India \\
\hline 15. & GSD 15 & Uttar Pradesh (Lucknow), India \\
\hline 16. & GSD16 & Uttar Pradesh (Lucknow), India \\
\hline 17. & GSD 17 & Uttar Pradesh (Lucknow), India \\
\hline 18. & GSD 18 & Uttar Pradesh (Lucknow), India \\
\hline 19. & GSD 19 & Gujarat (Mehsana), India \\
\hline 20. & GSD 20 & Uttar Pradesh (Lucknow), India \\
\hline 21. & GSD 21 & Uttar Pradesh (Lucknow), India \\
\hline 22. & GSD 22 & Uttar Pradesh (Lucknow), India \\
\hline 23. & GSD 23 & Uttar Pradesh (Lucknow), India \\
\hline 24. & GSD 24 & Uttar Pradesh (Lucknow), India \\
\hline 25. & GSD 25 & Uttar Pradesh (Lucknow), India \\
\hline 26. & GSD 26 & Gujarat, India \\
\hline 27. & GSD 27 & Uttar Pradesh (Lucknow), India \\
\hline 28. & $\mathrm{PL}^{*} 28$ & Malaysia \\
\hline 29. & GSD 29 & Uttar Pradesh (Lucknow), India \\
\hline 30. & GSD 30 & Uttar Pradesh (Lucknow), India \\
\hline 31. & GSD 31 & Uttar Pradesh (Lucknow), India \\
\hline 32. & $\mathrm{PL}^{*} 32$ & Malaysia \\
\hline 33. & GSD 33 & Uttar Pradesh (Lucknow), India \\
\hline
\end{tabular}




\begin{tabular}{|l|c|c|}
\hline 34. & GSD 34 & Gujarat, India \\
\hline 35. & PL* 35 & Hungary \\
\hline 36. & GSD 36 & Uttar Pradesh (Lucknow), India \\
\hline 37. & GSD 37 & Uttar Pradesh (Lucknow), India \\
\hline 38. & GSD 38 & Uttar Pradesh (Lucknow), India \\
\hline 39. & GSD 39 & Uttar Pradesh (Lucknow), India \\
\hline 40. & GSD 40 & Uttar Pradesh (Lucknow), India \\
\hline 41. & GSD 41 & Uttar Pradesh (Lucknow), India \\
\hline 42. & GSD 42 & Uttar Pradesh (Lucknow), India \\
\hline 43. & GSD 43 & Uttar Pradesh (Lucknow), India \\
\hline 44. & GSD 44 & Uttar Pradesh (Lucknow), India \\
\hline 45. & GSD 45 & Uttar Pradesh (Lucknow), India \\
\hline 46. & GSD 46 & Uttar Pradesh (Lucknow), India \\
\hline 47. & GSD 47 & Uttar Pradesh (Lucknow), India \\
\hline 48. & PA**48 & Italy \\
\hline 49. & PP***49 & Uttar Pradesh (Lucknow), India \\
\hline
\end{tabular}

Table 1: The genetic stocks/accessions and their places of collection/origin of Plantago species.

$\mathrm{GSD}=$ Plantago ovata, $\mathrm{PL}^{*}=$ Plantago lanceolata, $\mathrm{PA}^{* *}=$ Plantago arinaria, $\mathrm{PP} * * *=$ Plantago psyllium.

Moreover, the associations, co-heritability and path coefficient analysis were also computed as suggested by Dewey and Lu [9].

\section{Results and Discussion}

All the 50 accessions studied were diverse significantly among themselves for each of the 9 character examined $(\mathrm{p}<0.01 \%$ in ANOVA).

\section{Genetic variation}

The highest evaluated genotypic coefficient of variation $(\mathrm{GCV}=$ $214.44 \%$ ) were observed in panicles/plant, modest for swelling factor (70.29\%) followed by seed yield/plot (63.08\%) suggesting these are effective traits for further genetic improvement. The lowest GCV $=20.56 \%$ was displayed by plant height. The phenotypic coefficient of variation (PCV) was higher than their corresponding GCV for all the traits (Table 2), reflects that the manifested variation was not only due to genotypes but by environment also. The maximum amount of appraises PCV $=215.98 \%$ was displayed by panicles/plant, moderate swelling factor (71.42\%) followed by seed yield/plot (64.35\%). The lowest PCV (21.121\%) was exhibited by plant height. The nominal difference between PCV and GCV were projected in husk yield/plot $(0.16 \%)$ followed by plant height $(0.56 \%)$, suggesting that these traits were least effected by environment. These were also supported by higher values of heritability in broad sense (98.78\% and $94.85 \%$ ) for these traits respectively (Table 2). Broad difference PCV and GCV were noted for branches/plant (3.85\%) followed by panicle length $(3.37 \%)$, indicated that these characters were greatly inclined by environmental fluctuation. Hence, these traits are not fine for selection.

\section{Correlation between characters}

It was eminent from the result that genotypic correlation coefficients $\left(r_{g}\right)$ were higher than phenotypic correlation coefficients $\left(r_{p}\right)$ for all selected traits, implies that influence of environment had a little role in expression of characters, suggesting inherent relations between these selected traits at their genotypic level (Table 3). The morphometric character plant height depicted significant, positive genotypic and phenotypic correlation with panicle length (rg $\left.=0.59, r_{p}=0.54\right)$, peduncle length $\left(r_{g}=0.48, r_{p}=0.48\right)$ and swelling factor $\left(r_{g}=0.37, r_{p}=0.36\right)$ whereas branches/plant exhibited the same with seed yield $\left(r_{g}=0.20, r_{p}=0.20\right)$ and husk yield $\left(r_{g}\right.$ $=0.42, r_{p}=0.36$ ) indicating that superior plant height will escort the panicle length, peduncle length, inflorescence length and swelling factor whereas branches/plant led to increase the seed yield and husk yield. The panicle length showed the same response with panicle length and peduncle length. Seed yield depicted significant positive genotypic and phenotypic correlation with branches/plant $\left(r_{g}=0.20, r_{p}=0.20\right)$ indicating that the branches/plant directly affect seed yield positively. There was greatly significant negative correlation exhibited by plant height with branches/plant $\left(r_{g}=-0.68, r_{p}=-0.55\right)$ and swelling factor $\left(r_{g}=-0.75, r_{p}=-0.73\right)$ whereas branches/plant negatively correlated with panicle length $\left(r_{g}=-0.65, r_{p}=-0.45\right)$ and peduncle length $\left(r_{g}=-0.77, r_{p}=-0.63\right)$ indicating increasing plant height will led to reduction in branches/ plant and swelling factor which led to reduction in panicle length and peduncle length at both level (Table 3).

\section{Path-coefficient analysis}

The analysis of path coefficient suggested by Dewey and Lu (1959) and character contribution study is the effective measure of direct and indirect association and also depicts the relative importance of each traits contributing to the final product seed yield. 


\begin{tabular}{|l|c|c|c|c|c|c|c|c|c|}
\hline \multicolumn{1}{|c|}{ Genetic parameters } & $\mathbf{X 1}$ & $\mathbf{X 2}$ & $\mathbf{X 3}$ & $\mathbf{X 4}$ & $\mathbf{X 5}$ & $\mathbf{X 6}$ & $\mathbf{X 7}$ & $\mathbf{X 8}$ & $\mathbf{X 9}$ \\
\hline $\begin{array}{l}\text { Genotypic variance } \\
\text { (ô 2g) }\end{array}$ & 87.47 & 1.36 & 7495.01 & 1.36 & 102.04 & 124.59 & 8.55 & 7.53 & 111.74 \\
\hline $\begin{array}{l}\text { Phenotypic variance } \\
\text { (ô 2p) }\end{array}$ & 92.23 & 1.83 & 7603.52 & 1.66 & 106.72 & 130.01 & 8.89 & 7.63 & 115.33 \\
\hline $\begin{array}{l}\text { Genotypic coefficient } \\
\text { of variation (G.C.V.) \% }\end{array}$ & 20.56 & 24.25 & 214.44 & 32.59 & 34.27 & 33.76 & 63.08 & 24.89 & 70.29 \\
\hline $\begin{array}{l}\text { Phenotypic coefficient } \\
\text { of variation (P.C.V.) \% }\end{array}$ & 21.12 & 28.10 & 215.98 & 35.96 & 35.05 & 34.48 & 64.35 & 25.05 & 71.42 \\
\hline $\begin{array}{l}\text { Heritability (broad } \\
\text { sense) ĥ 2(BS) \% }\end{array}$ & 94.85 & 74.49 & 98.57 & 82.15 & 95.61 & 95.83 & 96.09 & 98.78 & 96.87 \\
\hline Genetic advance (GA) & 18.27 & 1.79 & 175.79 & 1.98 & 19.89 & 22.03 & 5.78 & 5.58 & 21.09 \\
\hline GA over mean (\%) & 40.17 & 37.13 & 435.44 & 55.15 & 67.49 & 66.63 & 38.43 & 120.51 & 191.37 \\
\hline
\end{tabular}

Table 2: Estimates of genetic parameters for nine selected economic traits in Plantago sp.

\begin{tabular}{|l|c|c|c|c|c|c|c|c|c|}
\hline Traits & X1 & X2 & X3 & X4 & X5 & X6 & X7 & X8 & X9 \\
\hline \multirow{2}{*}{ X1 } & - & $-0.68^{* *}$ & 0.15 & $0.59^{* *}$ & $0.48^{* *}$ & $0.5^{* *}$ & 0.13 & $-0.75^{* *}$ & $0.37^{* *}$ \\
& & $-0.55^{* *}$ & 0.15 & $0.54^{* *}$ & $0.48^{* *}$ & $0.5^{* *}$ & 0.12 & $-0.73^{* *}$ & $0.36^{* *}$ \\
\hline \multirow{2}{*}{ X2 } & 0.19 & - & 0.01 & $-0.65^{* *}$ & $-0.77^{* *}$ & $-0.76^{* *}$ & $0.20^{*}$ & $0.42^{* *}$ & 0.09 \\
& 1.03 & & 0.03 & $-0.45^{* *}$ & $-0.63^{* *}$ & $-0.62^{* *}$ & $0.20^{*}$ & $0.36^{* *}$ & 0.11 \\
\hline \multirow{2}{*}{ X3 } & 0.15 & 0.30 & - & $-0.39^{* *}$ & $-0.45^{* *}$ & $-0.45^{* *}$ & 0.07 & $-0.55^{* *}$ & $0.20^{*}$ \\
& 0.97 & 0.43 & - & $-0.34^{*}$ & $-0.44^{* *}$ & $-0.44^{* *}$ & 0.08 & $-0.55^{* *}$ & $0.20^{*}$ \\
\hline \multirow{2}{*}{ X4 } & 0.25 & 0.25 & 0.32 & - & $0.89^{* *}$ & $0.92^{* *}$ & 0.06 & -0.17 & 0.07 \\
& 0.95 & 1.11 & 1.04 & - & $0.81^{* *}$ & $0.85^{* *}$ & 0.06 & -0.15 & 0.07 \\
\hline \multirow{2}{*}{ X5 } & 0.49 & 0.25 & 0.07 & 0.18 & - & $1.00^{* *}$ & -0.08 & -0.04 & -0.11 \\
& 0.95 & 1.04 & 1.00 & 0.98 & - & $0.99^{* *}$ & -0.07 & -0.04 & -0.10 \\
\hline \multirow{2}{*}{ X6 } & 0.52 & 0.28 & 0.15 & 0.41 & 0.97 & - & -0.06 & -0.06 & -0.09 \\
& 0.95 & 1.04 & 1.00 & 0.96 & 0.96 & - & -0.06 & -0.06 & -0.08 \\
\hline \multirow{2}{*}{ X7 } & 0.06 & 0.32 & 0.41 & 0.11 & 0.07 & 0.09 & - & 0.06 & $0.94^{* *}$ \\
& 0.97 & 0.84 & 0.87 & 0.86 & 1.04 & 1.06 & & 0.07 & $0.95^{* *}$ \\
\hline \multirow{2}{*}{ X8 } & 0.06 & 0.10 & 0.11 & 0.07 & 0.01 & 0.03 & 0.26 & & -0.19 \\
& 1.00 & 0.98 & 1.00 & 1.02 & 1.00 & 1.01 & 0.92 & - & -0.19 \\
\hline \multirow{2}{*}{ X9 } & 0.09 & 0.32 & 0.41 & 0.08 & 0.09 & 0.11 & 0.98 & 0.24 & - \\
& 0.98 & 0.74 & 0.95 & 0.92 & 1.03 & 1.04 & 0.96 & 1.02 & - \\
\hline
\end{tabular}

Table 3: Genotypic $\left(\mathrm{r}_{\mathrm{g}}\right)$ and phenotypic $\left(\mathrm{r}_{\mathrm{p}}\right)$ correlation coefficients and co-heritability among 9 economic traits in Plantago sp.

Correlation due to genotype $=$ number at the top, correlation due to phenotype $=$ number below the top in above diagonal area, correlation due to environment $=$ number at the top, co-heritability in broad sense = number below the top in below diagonal area.

$$
\begin{aligned}
& \mathrm{p}^{*}<0.05 . \\
& \mathrm{p}^{* *}<0.01 .
\end{aligned}
$$




\begin{tabular}{|l|c|c|c|c|c|c|c|c|c|}
\hline Traits & $\mathbf{X 1}$ & $\mathbf{X 2}$ & $\mathbf{X 3}$ & $\mathbf{X 4}$ & $\mathbf{X 5}$ & $\mathbf{X 6}$ & $\mathbf{X 8}$ & $\mathbf{X 9}$ & $\begin{array}{c}\mathbf{r}_{\mathbf{g}} \text { value } \\
\text { (Seed yield) }\end{array}$ \\
\hline $\mathrm{X} 1$ & 0.35 & 0.01 & -0.0037 & -0.028 & -0.507 & 0.43 & 0.10 & 0.010 & 0.37 \\
\hline $\mathrm{X} 2$ & -0.24 & 0.015 & -0.0004 & 0.032 & 0.82 & -0.66 & 0.17 & -0.0057 & 0.096 \\
\hline $\mathrm{X} 3$ & 0.05 & -0.00023 & -0.025 & 0.019 & 0.479 & -0.39 & 0.061 & 0.0078 & 0.20 \\
\hline $\mathrm{X} 4$ & 0.20 & 0.0097 & 0.01 & -0.048 & -0.95 & 0.797 & 0.054 & 0.0024 & 0.079 \\
\hline $\mathrm{X} 5$ & 0.17 & 0.011 & 0.012 & -0.043 & -1.05 & 0.869 & -0.069 & 0.00069 & -0.12 \\
\hline $\mathrm{X} 6$ & 0.17 & 0.011 & 0.015 & -0.044 & -1.05 & 0.87 & -0.057 & 0.00088 & -0.093 \\
\hline $\mathrm{X} 8$ & 0.043 & -0.0029 & -0.0017 & -0.0029 & 0.082 & -0.056 & 0.88 & -0.00089 & 0.94 \\
\hline $\mathrm{X} 9$ & -0.26 & -0.006 & 0.014 & 0.008 & 0.053 & -0.054 & 0.056 & -0.014 & -0.20 \\
\hline
\end{tabular}

Table 4: Direct (in bold) and indirect effects of yield contributing traits on seed yield in Plantago sp.

$$
\text { Residual effect }=0.0825 ; r_{g}=\text { genotypic correlation. }
$$

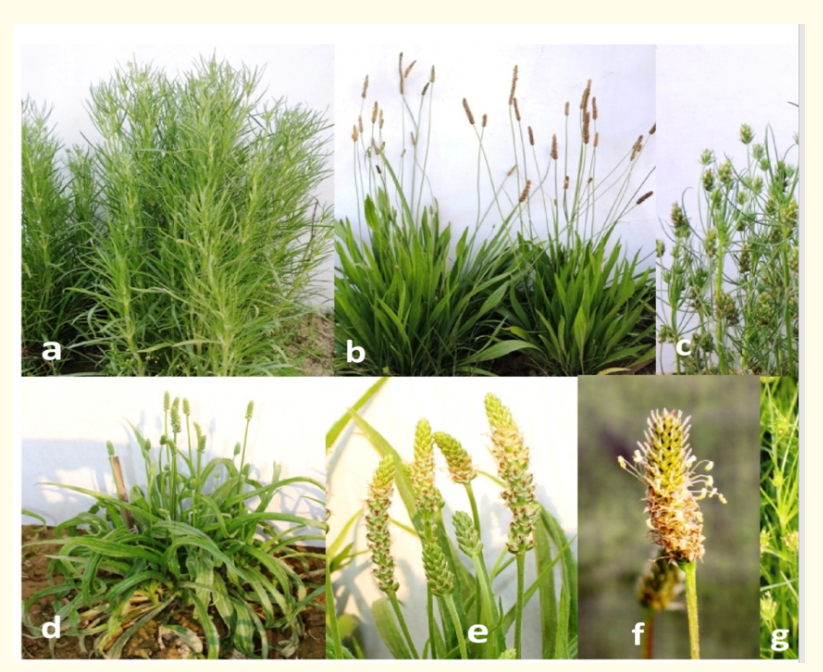

Figure 1: Whole plant of different Plantago accessions (a) P. arinaria, (b) P. lanceolata (c) P. psyllium (d) P. ovata and flower of different accessions (e) P. ovata (f) P. lanceolata (g) P. psyllium.

The largest direct contributor to seed yield were husk yield/plot (0.88) followed by inflorescence length (0.87), plant height (0.35) and branches/plant (0.015). Direct contribution of other traits towards seed yield was negative but the indirect contribution to seed yield was large through peduncle length (0.82). The maximum lower indirect contribution towards seed yield was through plant height $(0.20)$. The residual effect was very low $R=0.0825$ (Table 4 , Figure 2).

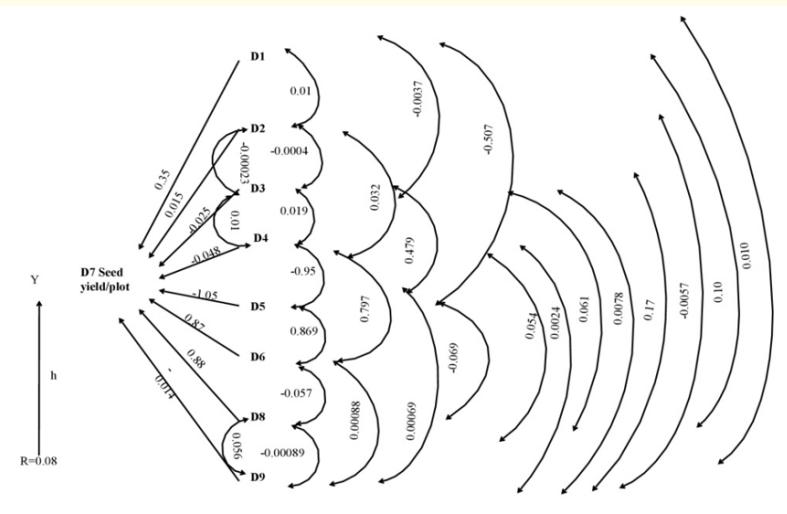

Figure 2: Genotypic path diagram for grain yield from 50 accessions of Plantago species.

Heritability of character

It is also played important role in character association and path analysis in genetic improvement of crops. The highest heritability in broad sense was noted for husk yield/plot (98.78\%) followed by panicles/plant (98.57\%), swelling factor (96.87\%) and seed yield/plot (96.09\%), suggesting that these traits are easy to select in Plantago crop. Because due to high heritability these traits were least influenced by environment. The low heritability was observed in branches/plant (74.49\%) followed by panicle 
length $(82.15 \%)$ indicates that selection of these traits are difficult due to environmental fluctuation. High heritability and highest genetic advance (GA) were observed for the traits panicle/plant (98.57\%, 157.79\%), suggesting it was possibly governed due to cumulative gene action (Khanna and Shukla, 1989) and therefore selection may be easy for this traits. According to the overall mean performance, character contribution, correlation, path coefficient analysis, heritability and genetic advance, accessions GSD 36, GSD 38, GSD 42, GSD 45, and GSD 47 were identified as highest seed yielding accessions. This finding shows coherence with the result of Sarkar and Lal [10] in this crop.

\section{Conclusion}

This investigation in Plantago germplasm unveil that the trait branches/plant had positive and significant correlation with seed yield. The path coefficient analysis revealed that the highest direct contributor to seed yield was husk yield/plot followed by inflorescence length and the lower highest indirect contribution towards seed yield was through plant height. The maximum heritability was also observed for husk yield/plot. High heritability and highest genetic advance were observed for the trait panicle/plant. This study suggests for the utilization of effectiveness of correlation, path analysis, heritability and genetic advance in developing reliable selection criteria in Plantago. Thus, on the basis of overall mean performance, character contribution, correlation, path coefficient analysis, heritability and genetic advance, accessions GSD 36, GSD 38, GSD 42, GSD 45, and GSD 47 of Plantago germplasm were found to be more suitable as high seed yielding accessions and could be exploited for commercial cultivation and industrial uses.

\section{Acknowledgements}

The first author acknowledges the University Grant Commission, Government of India for awarding Junior Research Fellowship for my Ph.D. work at University of Lucknow, Lucknow. The author also grateful to The Director, CSIR-Central Institute of Medicinal and Aromatic Plants for allowing me to work in CIMAP and for providing all the required facilities.

\section{Bibliography}

1. Mishra M and Khan AH. "Mutagenic effectiveness and efficiency of individual and combined treatments of EMS and gamma rays in Isabgol (Plantago ovata Forsk)". International Journal of Life Sciences 2.3 (2014): 212-216.
2. Anonymous. "The Wealth of India. Raw Materials". New Delhi: Publications and Information Directorate CSIR 8 (1969): 146151.

3. Lal RK., et al. "Genetic diversity in germplasm of isabgol (Plantago ovata)". Journal of Herbs Spices and Medicinal Plants 6 (1999): 73-80.

4. Chopra RN., et al. "Chopra's Indigenous Drugs of India”. 2nd edition. U.N. Dhar and Sons Pvt. Ltd., Calcutta (1958): 379385.

5. Dodiya NS and Khatik CL. "Mutagenic response of Isabgol (Plantago ovata Forsk) to gamma rays". International Journal of Plant Science (2014): 78-82.

6. Kawatra A., et al. "Hypocholestrolemic effect of Isabgol husk in overweight adults". Nutrition Research 10 (1990): 1177-1182.

7. Singh N and Lal R K. "Genetics of quantitative and qualitative traits of isabgol (Plantago ovata)". Genetics and Molecular Research 8 (2009): 939-950.

8. Panse VG and Sukhatme PV. "Statistical methods for agricultural workers". $2^{\text {nd }}$ edition. Indian Council of Agricultural Research, New Delhi" (1967).

9. Dewey DR and Lu KH. "A correlation and path analysis of components of crested wheat seed production". Agronomy Journal 51 (1959): 515-518.

10. Sarkar S and Lal RK. "Genetic variability of agronomical and economical traits in Psyllium germplasm". Industrial Crops and Products 65 (2015): 515-520.

\section{Volume 5 Issue 7 July 2021}

(c) All rights are reserved by Dilshad Ahmed and RK Lal. 